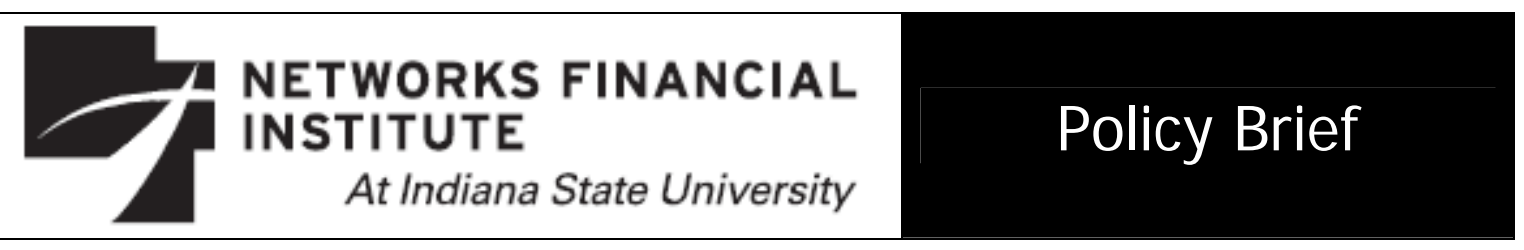

2007-PB-09

August 2007

\title{
The Long and Short of Housing: The Home Ownership Boom and the Subprime Foreclosure Bust John C. Weicher
}

Abstract: The increasing risks that subprime lenders have been willing to take have culminated in a debacle of rising foreclosures. So far, however, subprime defaults and foreclosures are lower than they were about five years ago, and the problem is likely to be confined to the subprime market, rather than the conventional mortgage market or the US economy. Extensive public and private efforts are being made to mitigate the problem. In addition, despite popular consensus to the contrary, house prices in general have not fallen over the past year, and few markets are experiencing a substantial decline. Lenders and regulators are both taking action to reform subprime lending, and the foreclosure problem is likely to be limited to the 2004-2006 ledgers of business. Meanwhile, there has been a long-term homeownership boom, extending broadly across American society and including minority groups with high immigration rates. This boom has been facilitated by the revolution in information technology, making it possible for lenders to measure risk more accurately, and by the growth of financial literacy initiatives and counseling. For these reasons, the subprime foreclosure problem is likely to be shortterm. Looking at individual markets, many areas in Indiana, Michigan and Ohio are having serious problems, though there are some grounds for hope that they will not experience the worst of the subprime debacle.

About the Author: John C. Weicher is Director of the Center for Housing and Financial Markets at Hudson Institute. From 2001 to 2005 he was Assistant Secretary for Housing and Federal Housing Commissioner at the U.S. Department of Housing and Urban Development, with responsibility for managing the FHA mortgage insurance programs, serving as “mission regulator” for Fannie Mae and Freddie Mac, and serving as the HUD Secretary's representative on the Board of Directors of NeighborWorks and the Federal Housing Finance Board. Dr. Weicher holds a Ph.D. in economics from the University of Chicago and an A.B. in English from the University of Michigan.

Keywords: Foreclosures, subprime lending, housing market, risk.

The views expressed are those of the individual author and do not necessarily reflect official positions of Networks Financial Institute. Please address questions regarding content to John Weicher at john@hudson.org. Any errors or omissions are the responsibility of the author. The author would like to thank Richard Goggins, Philip Schuster, and Xiuyue Zhu for research assistance.

NFI working papers and other publications are available on NFI's website (www.networksfinancialinstitute.org). Click "Research" and then "Publications/Papers." 
The Long and Short of Housing:

The Homeownership Boom and the Subprime Foreclosure Bust

Subprime mortgages dominate the economic news. They have pushed \$3-agallon gas off the front pages, and completely obscured the 4.5 percent national unemployment rate, and the economic expansion that has now lasted $51 / 2$ years and is the fourth longest expansion since World War II.

The common view seems to be that the sky is falling - or perhaps, to use a housing metaphor, the roof is falling in - not just in the subprime market, or the housing sector, but the entire U.S. economy and even the world. In this paper, I intend to put the subprime mortgage problem in perspective. As the same time, I do not at all intend to minimize the problem, for policymakers, lenders, and especially for subprime borrowers, many of whom apparently have been persuaded to take on highly leveraged debt instruments without having the possible consequences explained to them.

My focus is national, but I will conclude with some discussion of the local situation and outlook, in Indiana and the Midwest.

\section{The Subprime Market: Growth and Change}

The subprime market is new, and it has grown very fast. It barely existed 20 years ago; now, it constitutes about 15 percent of the home mortgage market, and may have accounted for 20 percent of home mortgage originations last year.

This dramatic growth appears to stem from three public policy changes.

First, the 1986 Tax Reform Act ended the federal income tax deductibility of consumer interest for all purposes except home mortgages. This adversely affected the 
market for consumer loans, and spurred the growth of home equity lending, particularly in the form of HELOCs (home equity lines of credit). Consumer lenders, seeing their traditional market drying up, began moving into home equity lending.

Second, and I think most important, was the Financial Institutions Reform, Recovery and Enforcement Act of 1989 (FIRREA), in the aftermath of the savings and loan collapse. FIRREA not only provided the funds and institutional arrangements for closing many failed S\&Ls, it also established a new regulatory framework for the surviving institutions. In particular, it set higher capital standards for home mortgages held in portfolio, for both traditional home mortgage lenders and commercial banks; and it required more stringent regulation and supervision of mortgage lenders by the financial regulatory agencies. After FIRREA, the traditional mortgage lenders and also banks often found it more profitable to operate as mortgage bankers - originating mortgages, but not keeping them in portfolio, selling them instead into the secondary market, usually to Fannie Mae and Freddie Mac. As portfolio lenders, S\&LS were able to adopt their own underwriting standards, within statutory and regulatory limits. As mortgage bankers, they perforce had to meet the GSEs' less flexible standards in order to sell or securitize their mortgages. Also, as local institutions, they were in a position to consider special circumstances for individual loans and borrowers. In the aftermath of the collapse, the surviving institutions tended to become regional and national, giving loan officers less room for local decision. And of course loans to risky borrowers in a bank’s portfolio did not appeal to regulators. As the traditional lenders therefore moved away from making relatively risky loans, they left an opportunity for the consumer lenders. 
The third policy was more amorphous: federal encouragement of a conventional mortgage-backed securities market. For many years the financial markets were only willing to accept MBS with an explicit or implicit federal guarantee. Market acceptance of MBS backed by conventional mortgages and issued by fully private institutions came slowly, but by the late 1980s conventional MBS were being successfully issued. During the early 1990s, subprime MBS were beginning to earn market acceptance.

Each policy served important public purposes. Taken together, they had the unintended consequence of facilitating the subprime mortgage market. From \$3 billion in subprime mortgages in 1988, as best the market could be measured, originations increased to \$38 billion in 1996 and then to over \$500 billion by 2004 .

Equally important, as the market grew, subprime lending changed. In the mid1990s I wrote the first systematic academic study of the subprime market, at the behest of a group of subprime lenders who had formed a nascent trade association. ${ }^{1}$ At that time, subprime loans were basically either refinances or debt consolidation, often first mortgages for people who already owned their homes, free and clear. Fewer than five percent were purchase money mortgages. In addition, LTVs on subprime loans were substantially lower than in the conventional prime market for home purchase loans, typically no more than 70 percent. Subprime lenders knew they were taking a great deal of risk, and they wanted protection against loss, as much as possible. Even at such low LTVs, subprime lenders typically lost about 30 cents on the dollar when they foreclosed, took title, and sold the home.

\footnotetext{
${ }^{1}$ John C. Weicher, The Home Equity Lending Industry: Refinancing Mortgages for Borrowers with Impaired Credit (Hudson Institute, 1997).
} 
By 2002, when as FHA Commissioner I had occasion to take a further look at the subprime market, it had changed. Home purchase loans now constituted about one-third of subprime originations - a much larger share, but still a minor fraction. LTVs were also quite a bit higher, but still nearly all were 90 percent or less; by comparison, nearly all FHA borrowers had LTVs above 95 percent.

By 2006, the home purchase share was up to 44 percent, but more importantly subprime loans now carried very high LTVs and were generally riskier in other respects as well.

Those risks are now coming home to roost.

Charts 1-3 show the pattern of subprime delinquencies and foreclosures back to the beginning of 1998, as far back as the Mortgage Bankers Association (MBA) has consistent data. The charts all show a big increase in 2007, as everyone knows. However, the current level, high as it is, is still below the levels reached during 20002002, particularly with respect to foreclosures. We are now experiencing the second sharp upturn in problem loans since the start of the decade, but the current rates are not outside historical experience. Moreover, it is worth remembering that many subprime lenders went out of business in the previous episode, but the industry as a whole continued to grow.

The relevance of the comparison should not be overstated. The defaults and foreclosures in 2000-2002 occurred on loans with LTVs of 90 percent or lower, as noted previously. Current defaults and foreclosures are on loans with LTVs close to 100 percent, and with other risky features. It is reasonable to expect defaults and foreclosures to be higher over the next couple of years than they were at the beginning of the decade. 
The point is that we have had similar experiences; the current situation is different in degree, not in kind.

Also, and this is probably more important than the precise levels of subprime defaults and foreclosures, there was no similar pattern - no echo of the subprime spike in the prime market. Delinquencies and especially foreclosures on prime mortgages remained low during the previous subprime debacle.

These charts suggest to me that the current problem is likely to be limited to the subprime market. It is not likely to be contagious and infect the prime market, although some prime lenders, and especially Wall Street analysts and the media, are expressing the opposite view.

It seems clear, moreover, that the problems are concentrated in the loan cohorts of 2004 to 2006. Before 2004, loans were less risky, and borrowers enjoyed the doubledigit home price appreciation of 2004 and 2005. Many have been able to refinance into conventional loans with better terms. Analysts have concluded that loans originated in 2003 and earlier pose no major problem, in general, although certainly some borrowers will still default on those loans. ${ }^{2}$

How large is the problem posed by the 2004-2006 subprime cohorts? Two recent analyses suggest upper and lower bounds.

The chairman of the MBA, John Robbins, offered a lower bound in a speech at the National Press Club in May. Restricting his discussion to subprime ARMs, he reported that 10.8 percent of these loans were in default and half would go to foreclosure.

\footnotetext{
${ }^{2}$ Christopher Cagan, “Mortgage Payment Reset: The Rumor and the Reality,” First American Real Estate Solutions, February 8, 2006.
} 
I calculate this at about 200,000 to 300,000 homeowners (the higher number includes subprime fixed-rate mortgages). ${ }^{3}$

Mr. Robbins was explicitly taking issue with a study issued by the Center for Responsible Lending last December, which projected default rates of 15 percent for the 2004 subprime cohort and 19 percent for the 2005 and 2006 cohorts. These are cumulative rates for the cohort over the full 30-year term of the loan. ${ }^{4}$ Since subprime loans, like FHA loans, typically default in the first few years if they are going to default at all, I have translated these cumulative default rates into annual rates over the next three to four years, amounting to about 500,000 to 600,00 homeowners each year.

To put these projections into the context of Chart 2, the lower numbers represent a quarterly rate of about 1.5 percent for loans entering foreclosure, and the higher numbers about 2.5 percent.

The outcome is likely to be somewhere in between. In my view, it is likely to be closer to the MBA projection, for reasons discussed in the remainder of the paper. But, either way or anywhere in between, it seems unlikely that annual foreclosures of 200,000 to 600,000 subprime loans are likely to threaten a disaster for the US economy, let alone the world.

\section{Mitigating the Impact of Subprime Foreclosures: Forbearance}

Public policies are also affecting lenders’ treatment of delinquent borrowers. The practice of forbearance is growing, encouraged by government agencies and the GSEs.

\footnotetext{
${ }^{3}$ John M. Robbins, "Chairman of Mortgage Bankers Association Addresses the National Press Club," Mortgage Bankers Association, May 22, 2007, http:/www.mortgagebankers.org/files/News/Internal Resource/54451_TextofSpeech.doc (accessed July 30, 2007).

${ }^{4}$ Ellen Schloemer, Wei Li, Keith Ernst, and Kathleen Keest, "Losing Ground Foreclosures in the Subprime Market and Their Cost to Homeowners,” Center for Responsible Lending (December, 2006).
} 
When borrowers fall behind on their loan, lenders do not automatically foreclose; instead, they try to see if they can help the owner stay in the home.

FHA began its forbearance program in 1999. It has grown rapidly, from 10,000 loans in forbearance that year to 70,000 per year in recent years. Typically, lenders are expected not to foreclose, but to work out a modified repayment plan, if there seems to be a realistic chance that the borrower can catch up. Often there is a realistic chance; about half of borrowers in forbearance are current on their loan within a year.

Conventional lenders apparently have a generally similar experience. It appears that somewhat more than half of conventional borrowers with forbearance are current within a year, perhaps about 60 percent. This appears to be the case for both prime loans sold to the GSEs, and subprime loans as well.

FHA and Wall Street have different reactions to these similar results. For FHA, forbearance is a good thing. These are families that otherwise would lose their homes, and FHA would incur a loss of about 25 to 30 cents per dollar on the outstanding principal balance. For Wall Street, forbearance is a problem. In recent months, analysts have regularly complained about how difficult forbearance makes it to value subprime MBS. Forbearance masks the default rate and hides the problems from investors. There is talk of forbearance as a "ticking time bomb." 5 To me, this is backward. Wall Street analysts are paid to evaluate complex securities amid various contingencies. Their complaints ignore the fundamental fact of fewer defaults. Without forbearance, the time bomb would be twice as big, and would explode sooner.

\footnotetext{
${ }^{5}$ Joseph R. Mason and Joshua Rosner, "How Resilient Are Mortgage Securities to Collateralized Debt Obligation Market Disruptions?,” Hudson Institute, February 15, 2007.
} 
As the subprime problem has worsened, the financial regulators have been encouraging forbearance. Their joint statement in April encouraged lenders who are financial institutions "to work constructively" with homeowners who cannot make their mortgage payments, particularly borrowers subprime ARMs, and to “consider prudent workout arrangements that increase the potential for financially stressed residential borrowers to keep their homes.” The guidance also recommended counseling, including specific programs, and suggested that instituions could receive "favorable Community Reinvestment Act consideration for programs that transition low and moderate income borrowers from higher cost loans to lower cost loans.”6

These efforts and policies are contributing to preventing foreclosures and helping families remain in their homes.

\section{Mitigating the Impact of Subprime Foreclosures: House Prices}

In addition, the underlying economic trends are favorable to homeowners. This may seem a surprising statement when housing starts have fallen by one-third in a year the sharpest one-year drop since the Census Bureau began publishing monthly data in 1959. In addition, interest rates have been rising. But housing starts and interest rates are notorious cyclical. A more meaningful indicator is house prices.

Before "subprime mortgages" captured the headlines, the hot topic in housing was the "housing bubble," with numerous comparisons to the Tulip Bubble of the $17^{\text {th }}$ century, the South Sea Bubble of the $18^{\text {th }}$ century, and of course the dot.com bubble. By definition, bubbles burst. Stories about the housing bubble were a media commonplace

\footnotetext{
${ }^{6}$ FDIC, “Statement on Working with Mortgage Borrowers,” Press Release PR-32-2007, April 17, 2007.
} 
during 2003-2005, with numerous predictions about when the bubble would burst. ${ }^{7}$ With the downturn in housing starts last year, even before the subprime debacle, the conventional wisdom became that the bubble has burst.

This is not accurate. Economic "bubbles” are changes in asset prices: a rapid increase in asset prices followed immediately by a sharp fall in asset prices.

The best house price data is the House Price Index produced by the Office of Federal Housing Enterprise Oversight (OFHEO). This is a repeat sales price index, measuring changes in price for the same house from one sale to the next. As financial safety and soundness regulator of the GSEs, OFHEO has the records of millions of loans purchased by the GSEs, going back more than 30 years. These records enable OFHEO to compute national, regional and metropolitan price indexes dating back to 1975.

During those 30 years, there has been a steady upward trend in house prices, and that trend is still continuing, as Chart 4 shows. There have been price increases in 117 out of 125 quarters, including every quarter since 1993.

What has happened recently is that the rate of price increase has decelerated, very sharply. During 2004-2005, prices increased at double-digit rates. Over the last four quarters, ending in the first quarter of 2007, the rate of increase has been only about four percent. That is a much lower increase, but still an increase.

It is an odd sort of bubble, with prices still rising.

One reason for the common belief that the bubble has burst is that people do not bother to define “bubble,” or to quantify it. What does a bubble actually look like?

The Federal Deposit Insurance Corporation is very interested in house prices, for obvious reasons. FDIC's economists have studied the OFHEO data covering the last 30

\footnotetext{
${ }^{7}$ Howard Kurtz, “Bubble Bath of Doom!,” Washington Post, July 4, 2005, p. C01.
} 
years, analyzing the patterns of price changes in local markets, and they have developed a definition of a housing cycle that is grounded in reality and comes much closer to describing market behavior than the notion of a "bubble.",

FDIC's definition is shown in Chart 5: a 30 percent cumulative real increase in house prices over three years, followed by a 15 percent cumulative nominal decrease over five years. To put both changes in the same terms, I have adjusted the real increase by the annual average rate of inflation over the last six years. This translates into a cumulative nominal increase of $40-45$ percent followed by the 15 percent decrease - a net increase of more than 25 percent over eight years.

This is not the pattern of the NASDAQ Composite Index between 1995 and 2003. Chart 5 looks more like a "slow leak" on the downside than a bubble. But this is the typical pattern when local housing markets weaken. Prices do not drop like stones; they gradually edge downward.

By this definition, FDIC has identified ten boom/bust cycles - ten "bubbles” or “slow leaks” during 1978-1998: four in southern California, one in Honolulu, five in New England. This is out of 280 markets over a 20-year period. FDIC has also split the cyclical pattern between the upward and downward phases to identify boom and bust periods. Over those 20 years, there were 59 booms and 26 busts. As these data show, most booms were not followed by busts. ${ }^{9}$

\footnotetext{
${ }^{8}$ The following discussion is based on the Statement of Richard A. Brown, Chief Economist at FDIC, on "The Housing Bubble and its Implications for the Economy," before the Subcommittee on Housing Policy and the Subcommittee on Housing and Transportation of the U.S. Senate Committee on Banking, Housing, and Urban Affairs, September 13, 2006..

${ }^{9}$ Because the analysis begins with 1978, it may understate the number of boom/bust cycles. About ten busts occurred during the late 1970s and early 1980s in Texas and other "oil patch" states.
} 
As of the end of 2006, there were 104 ongoing booms and no busts, but of course prices have decelerated only over the last year or so. The FDIC model can be applied to OFHEO data to identify incipient busts - potential bubbles.

The most recent data, for the first quarter of this year, indicates that there may be quite a few busts, but they are just starting. During the first quarter, about one-sixth of US metropolitan areas (49 of 282, or 17 percent) experienced a price decline of $0.81 \%$ or more, which if continued for five years would meet the FDIC criterion of a bust. (Seven of the 36 markets in Indiana, Michigan, and Ohio, or 19 percent, would meet the criterion.)

But very few markets have experienced a "slow leak” over a period as long as a year (a price decline of 3.2 percent or more) - only ten: eight in California, one in Nevada, and one in Florida. The only large metropolitan area is Sacramento. The largest decline is in Punta Gorda, Florida, at 4.57 percent during the year (after a 95 percent increase in the previous four years); if that rate of decrease were to continue for another two and a half years, Punta Gorda would qualify as a boom/bust cycle - a bubble.

Over more than a year, there are only four markets on course for a bust: Santa Barbara, Kokomo, Anderson, and Sacramento. Kokomo had the worst decline in prices during 2006, followed by a slight increase in the first quarter of $2007 .^{10}$

Besides the imprecision with which we quantify bubbles, I think there is another reason why people generally believe the housing bubble has burst. We appear to be seeing an “expectations bubble.” Expecting prices to keep rising, sellers set asking prices that turned out to be unrealistic. They have had to cut their asking prices. However, they

\footnotetext{
${ }^{10}$ It should be emphasized that the calculations and enumerations in the foregoing paragraphs are my own analysis using the FDIC definition and OFHEO data, not those of either agency. I am responsible for any errors, including arithmetic ones.
} 
are still typically able to sell the house for more than they paid for it, just not as much more as they expected and hoped. As a convenient example, a young family bought the house next door to us in 2005. By early 2007 they decided to sell it. Their asking price was 30 percent above their purchase price two years earlier. This proved to be optimistic; they had to settle for 20 percent above their purchase price. That was disappointing to them, but still a very nice rate of return.

I have focused on the OFHEO index because it makes the appropriate comparison: what is happening to the price of a house over time - a typical house, or your house? This is the relevant comparison for homeowners confronting a personal financial problem or an adjustment to their loan payment. However, there is also an index of new home prices, published quarterly by the Census Bureau, and this index reports a 2.4 percent decline in the second quarter of 2007. This index is less appropriate than the OFHEO index, and does not take into account as many attributes of a house as might be desirable. In addition, it is more volatile. Nonetheless, it could be harbinger of greater deterioration in house prices than I think likely.

House prices matter for thinking about subprime foreclosures, because underlying everyone's projection about the subprime market, or the housing market in general, is some explicit or implicit forecast of house prices.

\section{The Future for Subprime Lending: Regulation}

The problems of the 2004-2006 subprime loan cohorts are likely to be limited to those cohorts. By the end of 2006, lenders were tightening their standards for subprime loans. The financial regulators issued guidance to financial institutions on nontraditional 
mortgage product risks in October 2006, and followed it with guidance on subprime

lending in June 2007. ${ }^{11}$ The former guidance urged institutions to recognize that nontraditional mortgages are "untested in a stressed environment," and require strong risk management and capital standards and loss reserves commensurate with the risk. The later guidance expressed concern about the "heightened risks" to lenders as well as borrowers from suprime ARMs with teaser rates such as 2/28 and 3/27 loans, loans with very high or no payment or rate caps, low-doc and no-doc loans, and substantial prepayment penalties, and stated that institutions should develop strong control systems in order to manage the risks.

This guidance also applies to Fannie Mae and Freddie Mac, but with a lag. OFHEO notified Fannie Mae and Freddie Mac in December 2006 that they were required to comply with the guidance on non-traditional mortgage product risks, but the GSEs did not agree to comply until July 2007, and they will continue to buy mortgages that do not comply until September 2007. Similarly, OFHEO has told the GSEs that they must follow the later statement on subprime mortgage lending; the agencies have said they will be issuing such rules sometime in the near future. ${ }^{12}$ There is evidence that the GSEs have bought large volumes of subprime MBS in order to meet their statutory affordable housing goals, even though the goals are based on the volume of business in the prime market. In 2005 the GSEs apparently bought 33 percent of all subprime MBS, and in

\footnotetext{
11 "Federal Rinancial Regulatory Agencies Issue Final Guidance on Non-Traditional Mortgage Product Risks,” FDIC Press Release PF-86-2006, September 29, 2006 (guidance in Federal Register, Vol. 71, no. 192, October 4, 2006, pp. 58609-58618); "Federal Financial Regulatory Agencies Issue Final Statement on Subprime Mortgage Lending,” FDIC Press Release PR-55-2007, June 29, 2007 (statement in Federal Register, Vol. 72, no. 131, July 10, 2007, pp. 37569-37575). The agencies are: the Office of the Comptroller of the Currency, the Board of Governors of the Federal Reserve System, the Federal Deposit Insurance Corporation, the Office of Thrift Supervision, and the National Credit Union Administration. ${ }^{12}$ James B. Lockhart III, “Housing, Subprime, and GSE Reform: Where are we headed?” speech to the Exchequer Club of Washington, DC, July 18, 2007.
} 
2006 they apparently bought 20 percent. ${ }^{13}$ Half of their private label MBS purchases were subprime. ${ }^{14}$ According to HUD, which as "mission regulator" for the GSEs is responsible for setting the level of the goals and monitoring performance, the GSEs have traditionally bought large volumes of private label MBS that have a high proportion of loans that count toward the goals. HUD indicates that purchases of private label MBS directly affected the ability of Freddie Mac to meet one of the goals in 2005; Fannie Mae, with a lower volume of purchases, failed to meet the goal. ${ }^{15}$

\section{The Future for Subprime Lending: Education}

Regulation is being complemented by consumer education. Substantial efforts are being made by both public and private entities to educate lower-income, poorly-educated consumers about financial matters, often with particular reference to housing. As former Federal Reserve Governor Edward M. Gramlich has pointed out, "There is already a huge effort to promote financial literacy."16 That effort is expanding, and will expand further. The financial regulators have created their own literacy programs, and have been reminding lenders about them.

Financial literacy activities are both national and local. There are particular efforts to reach immigrants, who confront language barriers and differences in the financial systems and economies between the US and their country of origin. A good example is the "Financial Access for Immigrants" program of the Federal Reserve Bank

\footnotetext{
${ }^{13}$ OFHEO, “Mortgage Markets and the Enterprises in 2006,” June 2007, p. 24.

${ }^{14}$ OFHEO, “2007 Report to Congress,” March 2007, Historical Data Tables, Table 1b, Part 2 for Fannie Mae; Table 10b, Part 2 for Freddie Mac

${ }^{15}$ Paul B. Manchester, "Goal Performance and Characteristics of Mortgages Purchased by Fannie Mae and Freddie Mac, 2001-2006,” HUD/Office of Policy Development and Research Housing Finance Working Paper Series, Working Paper HF-017, May 2007, p. 15.

${ }^{16}$ Edward M. Gramlich, Subprime Mortgages: America's Latest Boom and Bust (Urban Institute, 2007), p. 94.
} 
of Chicago. This program has brought together organizations from across the Seventh Federal Reserve District, and other parts of the country, to exchange information about helping immigrants achieve financial literacy. I participated in a conference sponsored by the Bank some three years ago, at which among other topics a number of local commercial banks described how they were reaching out to serve their nearby immigrant communities, or opening branches in these communities. ${ }^{17}$

At the federal level, since 2004 there has been a National Commission on Financial Literacy and Education, co-chaired by the Treasury Secretary and the Chairman of the Federal Reserve Board, bringing together the numerous federal agencies - and they are numerous - with financial literacy programs, and combining them with private and other programs in a National Strategy for Financial Literacy. ${ }^{18}$ The Commission includes the financial regulatory agencies, other regulatory agencies such as the Federal Trade Commission, and a number of Cabinet departments such as HUD, VA and USDA, which all have mortgage insurance or guaranty programs.

The Government Accountability Office has criticized the National Strategy as being “comprehensive but largely descriptive.” ${ }^{19}$ This may be true, but it misses an important point, with respect to the federal programs, at least. Publicizing specific programs as part of a national strategy creates a bureaucratic imperative to give the programs a higher priority and conduct them effectively. Program managers can anticipate more extensive and intensive scrutiny from GAO, the Office of Management

\footnotetext{
${ }^{17}$ Anna Paulson, Audrey Singer, Robin Newberger, and Jeremy Smith, "Financial Access for Immigrants: Learning from Diverse Perspectives,” Federal Reserve Bank of Chicago and The Brookings Institute (May, 2006).

18 “Taking Ownership of the Future,” Financial Literacy \& Education Commission (2006).

19 "Financial Literacy and Education Commission: Further Progress Needed to Ensure an Effective National Strategy,” United States Government Accountability Office (December, 2006), p. 10.
} 
and Budget, Congress (especially but not exclusively members of the opposite party), and the media.

It is important to distinguish these efforts from traditional "financial literacy" education programs for high school students, often considered to be ineffective. ${ }^{20}$ One reason is that high school students do not face significant real financial decisions. Most of the federal and private programs are aimed at adults, for whom the issues are real and often immediate. There is some reason to believe that these programs are more effective. $^{21}$

Probably the most immediately relevant activity is counseling. Hundreds of organizations around the country provide counseling for families that are making decisions about housing: whether to buy, what to do when they have problems, how to react to actions by their landlord, etc. (Counselors tend to focus primarily on buying a home, since that is the largest financial decision most families ever make, but they also provide information and advice about keeping a home when the owner gets into financial difficulties, and thus are helping to mitigate the current subprime foreclosure problem.) HUD has a list of approved counseling agencies, which is not intended as an exhaustive list. The HUD list includes 50 agencies in Indiana, 10 of them in Indianapolis.

HUD also provides funds to counseling agencies. In 2006 these HUD-funded agencies provided counseling to over 1.5 million individuals and families, including about 175,000 with mortgage delinquency problems. ${ }^{22}$

\footnotetext{
${ }^{20}$ Lewis Mandell, “Financial Literacy: If It’s So Important, Why Isn’t It Improving?,” Networks Financial Institute (April, 2006).

${ }^{21}$ Robert I. Lerman and Elizabeth Bell, “Financial Literacy Strategies: Where Do We Go From Here?,” The Urban Institute (August, 2006).

${ }^{22}$ The activities of HUD-funded counseling agencies are reported at: http://www.hud.gov/offices/hsg/sfh/hcc/FY06_All_Cumulative_Totals.pdf
} 
Counseling is effective. FHA collects information on whether borrowers have received housing counseling; the data show that those who were counseled are significantly less likely to default. Freddie Mac reports similar results for its portfolio; counseled borrowers are less likely to become delinquent. ${ }^{23}$ These findings have led the Administration to propose, and Congress to approve, substantial increases in funding for housing counseling from \$20 million in fiscal year 2001 to \$45 million in each of the last three years.

The regulatory guidance to financial institutions indicates that the 2007 subprime cohort will have lower default and foreclosure rates than 2004-2006, although the lag in GSE compliance will be an offsetting factor. The additional emphasis on forbearance and especially counseling should also mitigate subprime foreclosures in 2007 and beyond.

\section{A longer view: the homeownership boom}

It is useful to step back from the current concerns about subprime mortgages and housing bubbles and consider some fundamental phenomena that are more important in the longer term and give some context to the headlines of today and recent years.

The most important is the remarkable growth in homeownership. As Chart 6 shows, the homeownership rate among American households has been rising strongly for more than a decade. The record homeownership is 69.2 percent of all households in the fourth quarter of 2004. The rate has remained close to that level until this year, declining to 68.2 percent in the second quarter. Even with this recent decline, the homeownership

\footnotetext{
${ }^{23}$ Abdighanni Hirad and Peter M. Zorn, "A Little Knowledge is a Good Thing: Empirical Evidence of the Effectiveness of Pre-Purchase Homeownership Counseling,” Freddie Mac, May 22, 2001.
} 
rate is up by about 4-5 percentage points of the population over 10-12 years. That represents about five million households. This has been the largest increase for any decade since right after World War II.

Homeownership has also been increasing for minority groups, and has also been setting records. Chart 6 shows the homeownership rates for African-Americans and Hispanic Americans since 1994 (the earliest date for which annual and quarterly data are available). It is not explicit on these charts, but obviously there is a marked disparity between whites and minority households. The homeownership rate for whites is about 75 percent, while that for minority households as a whole is about 50 percent (75.4 percent and 50.8 percent, respectively, in the second quarter). The rate is below 50 percent for African-Americans, and just at 50 percent for Hispanic Americans. As Chart 6 shows, the rate for Hispanic households has recently passed that for African-Americans. It has risen by about eight percentage points since 1994 .

This is impressive and unexpected, given the high rate of Hispanic immigration. Immigrants have not typically bought homes shortly after they arrive in this country. Rapid immigration would normally be pulling the homeownership rate down. Instead, even though the number of immigrants has grown dramatically, the number of homeowners has grown faster. In the last 10 years, the number of Hispanic households has increased by 4 million, almost 50 percent more than the 8.6 million in the second quarter of 1997. At the same time, the number of Hispanic homeowners has increased by 2.6 million, about 70 percent more than the 3.7 million ten years ago. A similar pattern holds for the Census Bureau’s residual category of “other” households, which has also been rapidly increasing. This category consists primarily of Asian-Americans, though it 
also includes Native Americans and some smaller groups. Since the beginning of 2003, when consistent data become available, the number of "other” households has risen by 725,000, a 17 percent increase, while the number of “other” homeowners has increased by 600,000, and 25 percent increase, and the “other” homeownership rate has risen from 56.6 percent to 60.6 percent. $^{24}$

Part of the explanation for the increasing homeownership rates among these groups, at least in a statistical sense, is probably that immigrants who are citizens have almost the same homeownership rate as native-born Americans: 66 percent for the former, 67 percent for the latter. Immigrants who are not, or not yet, citizens have a homeownership rate under 40 percent. There is no difference in homeownership rates between young citizen immigrants and young native-born Americans. ${ }^{25}$

\section{The Information Revolution Comes to the Mortgage Market}

The desire for homeownership has always been strong. The National Association of Home Builders likes to say that “owning your own home is the American dream,” and NAHB is right. Given this strong and long-established preference, why has the homeownership rate increased so much in recent years?

The most important reason is technology. As the information revolution has permeated the housing market and the mortgage market, lenders have been much better

\footnotetext{
${ }^{24}$ In the first quarter of 2003 the Census began reporting a category of "two or more races." The number of households reported as "other" dropped by 511,000 from the fourth quarter of 2002, almost 11 percent.

${ }^{25}$ Sherrie Kossoudji, "Session 3: Housing and Homeownership,” Federal Reserve Bank of Chicago, April 15-16, 2004, http://www.chicagofed.org/community_development/FAI_Center_National_Conference_ Agenda.cfm (accessed July 30, 2007) to be published in Research in Labor Economics, forthcoming; kossoudj@umich.edu.
} 
able to measure risk than they used to be. They can make more informed and more accurate judgments with respect to who is likely to default on a mortgage.

While serving at HUD as Assistant Secretary for Policy Development and Research during the administration of President George Bush over 15 years ago, I was much involved in helping to restructure the FHA home mortgage program, which in the words of an actuarial analysis by PriceWaterhouseCoopers, was "solvent but not sound," with default rates rising. In developing our reform proposals, we focused on the initial LTV as the best predictor of default. Congress set the FHA mortgage insurance premium structure, in statute, in terms of the initial LTV. That was what lenders looked at, conventional lenders as well as FHA.

We did not have credit histories 15-20 years ago. Now we have credit histories summarized in FICO scores, and we know that credit history is a better predictor of default than initial LTV. Credit histories distinguish prime from subprime borrowers.

We also have automated underwriting systems which combine the information about the borrower and the home and the mortgage and enable the lender to make a fast decision on the loan application. We did not have this technology 15-20 years ago.

FHA, which of course has long served higher-risk borrowers than conventional lenders, has developed the TOTAL Scorecard (Technology Open To All Lenders), an algorithm to assess risk, and tell lenders whether a given loan will be automatically insured by FHA, or whether it must be manually underwritten. (It is not politically acceptable to deny FHA insurance on the basis of a statistical procedure without appeal to human judgment. Partly for that reason, FHA has not used FICO scores in approving loans.) TOTAL is not an automated underwriting system, but rather an algorithm that 
can be used as part of a lender's own AUS. With TOTAL, FHA can do a better job of evaluating risk at the high-risk end of its market; it can tell who is a "good high-risk" and who is a "bad high-risk" borrower. FHA can therefore move farther down in the risk spectrum, and also farther down in the income distribution, and serve more minority households.

Subprime lenders also have taken advantage of the new technology. And as Charts 1-3 show, they have used that technology to take more risk, and indeed have sometimes overshot their ability to measure risk. When I wrote my book about subprime lenders in the mid-1990s, the annualized foreclosure rate for subprime loans was 3.1 percent. Now it is 10.8 percent, according to the MBA, and perhaps rising, according to the Center for Responsible Lending’s projection.

\section{The National Conclusion: The Subprime Debacle in Perspective}

The rise in subprime foreclosures is real and likely to be large. Many homebuyers will find themselves in over their head, with loans whose terms they do not really understand. Whether the number of foreclosures turns out to be 200,000 per year or 600,000 per year, these are real families who are losing their homes, and their savings. For them, it is a disaster; for the housing sector, it is a debacle.

From a policy standpoint, this serious problem is probably a short-term problem, mainly limited to subprime mortgages originated during 2004-2006. It will be mitigated by public and private efforts to help the families in distress. There is no reason for it to spread to the prime market. Homeowners who are able to make their payments are not 
going to put themselves in position to lose their homes because other homeowners are losing theirs.

Moreover, the short-term subprime debacle will be limited by the long-term fundamentals in the housing and mortgage markets: the strong demand for homeownership, facilitated by the new information technology and determined policy efforts. The roof is not caving in on housing, let alone on the US or world economy.

\section{All Housing Markets are Local: Indiana and the Midwest}

Turning from this broad national perspective, it is both sobering and encouraging to look at Indiana and nearby states. I am not an expert on the individual markets, but there are several national sources of comparative information about local markets and I have lived or worked in several Midwestern states.

This discussion focuses on Indiana, Michigan and Ohio, because there seems to be a marked difference between the markets in these states and the states west of Indiana.

Table 1 reports data by state from MBA. Indiana, Michigan and Ohio are among the top six states in mortgage delinquencies. They are the top three states in foreclosures - both homes starting foreclosure and homes in foreclosure. This is indeed sobering.

The remaining tables report information for individual markets, typically Metropolitan Statistical Areas. Table 2 reports FHA foreclosures. Each month, FHA issues a "Report to the Commissioner," which among other information lists the 50 markets with the highest foreclosure rates. When I became Commissioner in 2001, California markets dominated the list. By 2003, the highest rates were in markets around New York City. In 2005, when I left FHA, Memphis topped the list. The latest 
published data are for March 2007. Sixteen of the worst 25 are in Ohio, Michigan or Indiana. Six of the worst seven are in Michigan and Ohio; \#4 is New Orleans.

Table 3 presents a similar picture. This is taken from the OFHEO house price index data for individual markets, showing the 25 markets with the smallest cumulative price increases over the last five years. These are markets that never had a boom, at least not recently. Nineteen of the 25 are in these three states. Here Indiana shows up with the weakest appreciation, with Anderson and Kokomo the lowest. Three of the four that have had less than 10 percent appreciation are in Indiana; the other is Detroit.

Tables 4 and 5 are more encouraging. Table 4 reports the OFHEO data for the most recent year, the markets where prices have dropped the most. Three of the weakest 25 are in Michigan; none are in Indiana or Ohio, though Kokomo is \#28 and Lima \#32. Finally, Table 5 reports the Center for Responsible Lending's projection of subprime foreclosures for loans originated in 2006. This is based on CRL's forecast of house prices, and the best guide to future price changes is past price changes, so CRL's projection should look somewhat like the OFHEO index for the past year. In fact, it is more encouraging than any of the others. There is only one Michigan city in the worst 25. The worst in Indiana is again Kokomo, but only at \#69; the worst in Ohio is Mansfield, at \#97.

The current and the most backward-looking indicators suggest especially serious problems in Indiana, Michigan and Ohio; the more forward-looking indicators suggest that problems will be less serious.

The most obvious factor in these patterns is the American automobile industry. Detroit's problems are well known. Flint has traditionally been known as “a Buick plant 
with a town around it.” And in Indiana, Kokomo and Anderson bring to mind the problems of auto parts manufacturers Delco and Delphi. Many of the Ohio areas have specialized in autos or auto parts.

Beyond autos, these tend to be areas that have suffered consistently high unemployment rates, and they tend to be smaller areas, with narrower economies. They are generally places that have not participated in the housing boom, or the economic boom of recent years. But apparently they have not share in the wild and crazy subprime lending boom, either, so they may not suffer the worst of the debacle. 


\section{Table 1: The States with Problems}

Top Delinquency

1. Mississippi

2. Louisiana

3. Michigan

4. Georgia

5. Indiana

6. Ohio
Foreclosure Inventory

1. Ohio

2. Indiana

3. Michigan
Foreclosure Starts

1. Ohio

2. Indiana

3. Michigan 


\section{Table 2: Highest FHA Default Rates \\ March 2007 (371 Markets)}

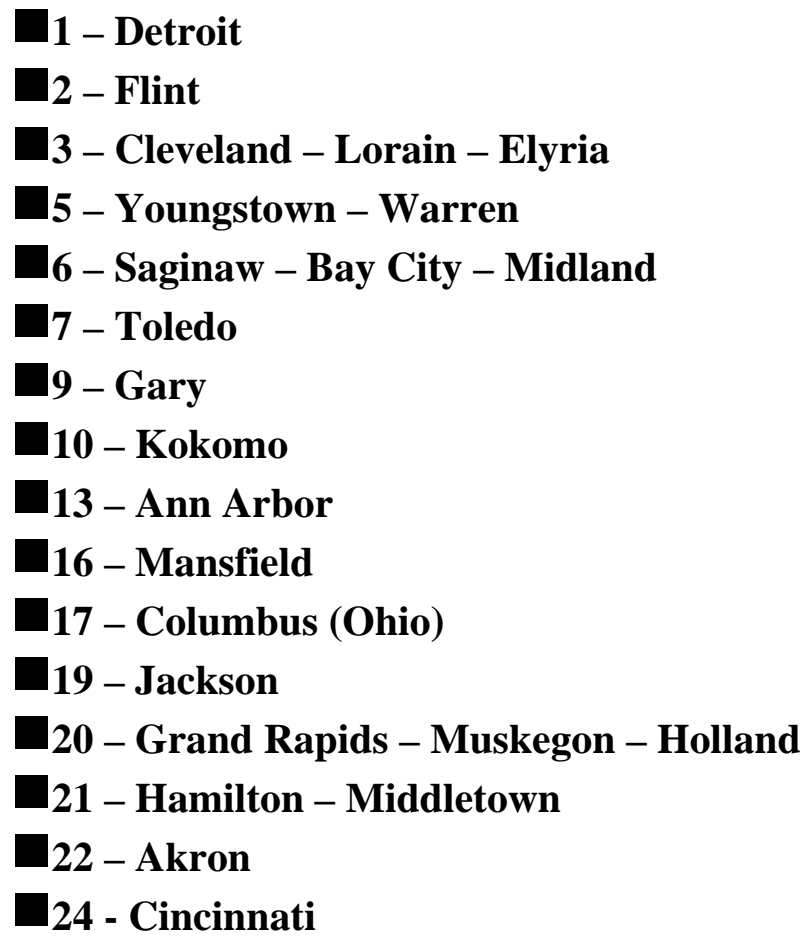

Source: FHA 


\section{Table 3: Smallest Five-Year Price Increases} (282 Markets)

$$
\begin{aligned}
& \text { D - Anderson (5\%) } \\
& \square_{2} \text { - Kokomo (6\%) } \\
& \text { 口 } 3 \text { - Detroit (8\%) } \\
& \text { Q } 4 \text { - Lafayette (8\%) } \\
& \text { } 5 \text { - Flint } \\
& \text { } 6 \text { - Warren, MI } \\
& \text { घ8 - Canton } \\
& \text { 9 - Saginaw } \\
& 10 \text { - Springfield, } \mathrm{OH} \\
& \text { D11 - Fort Wayne } \\
& \text { } 12 \text { - Akron } \\
& \text { ■14 - Mansfield } \\
& 15 \text { - Dayton } \\
& \text { } 16 \text { - Toledo } \\
& \text { 口17 - Cleveland } \\
& \text { } 19 \text { - Youngstown } \\
& \text { 口20 - Muskegon } \\
& \text { 口21 - Ann Arbor } \\
& \text { 口22 - Indianapolis (14.5\%) }
\end{aligned}
$$

Source: OFHEO 


\section{Table 4: Biggest One-Year Home Price Declines} (282 Markets)

11 - Bay City

13 - Detroit

口 15 - Flint

28 - Kokomo

32 - Lima

Source: OFHEO 


\title{
Table 5: Highest Projected Subprime Foreclosure Rates (2006 Loan Cohort) \\ (378 Markets)
}

\author{
15 - Saginaw \\ 69- Kokomo \\ 97 - Mansfield
}

Source: Center for Responsible Lending 


\section{Chart 1: Mortgage Delinquency}

(30-day)

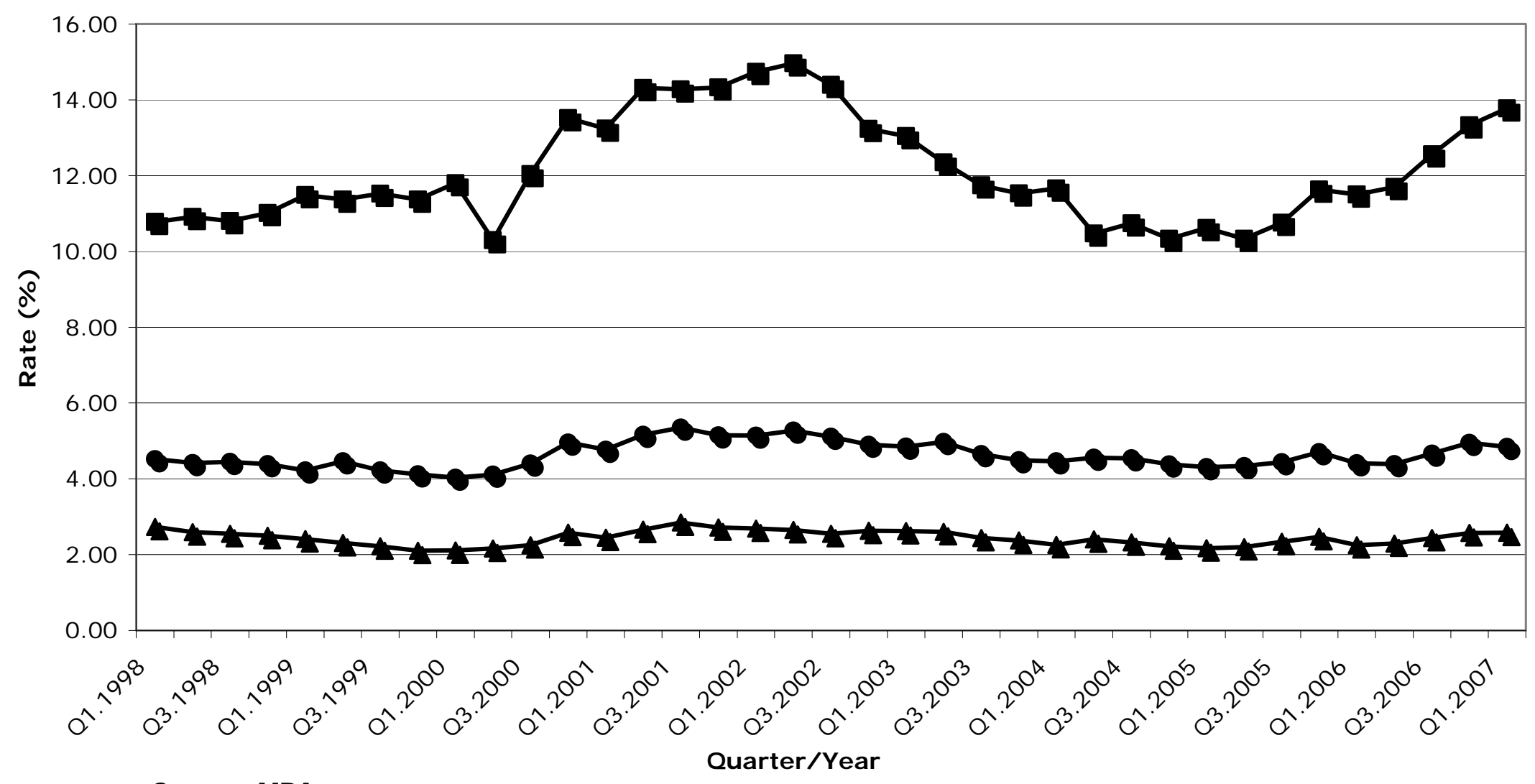

Source: MBA 


\section{Chart 2: Homes Entering Foreclosure}

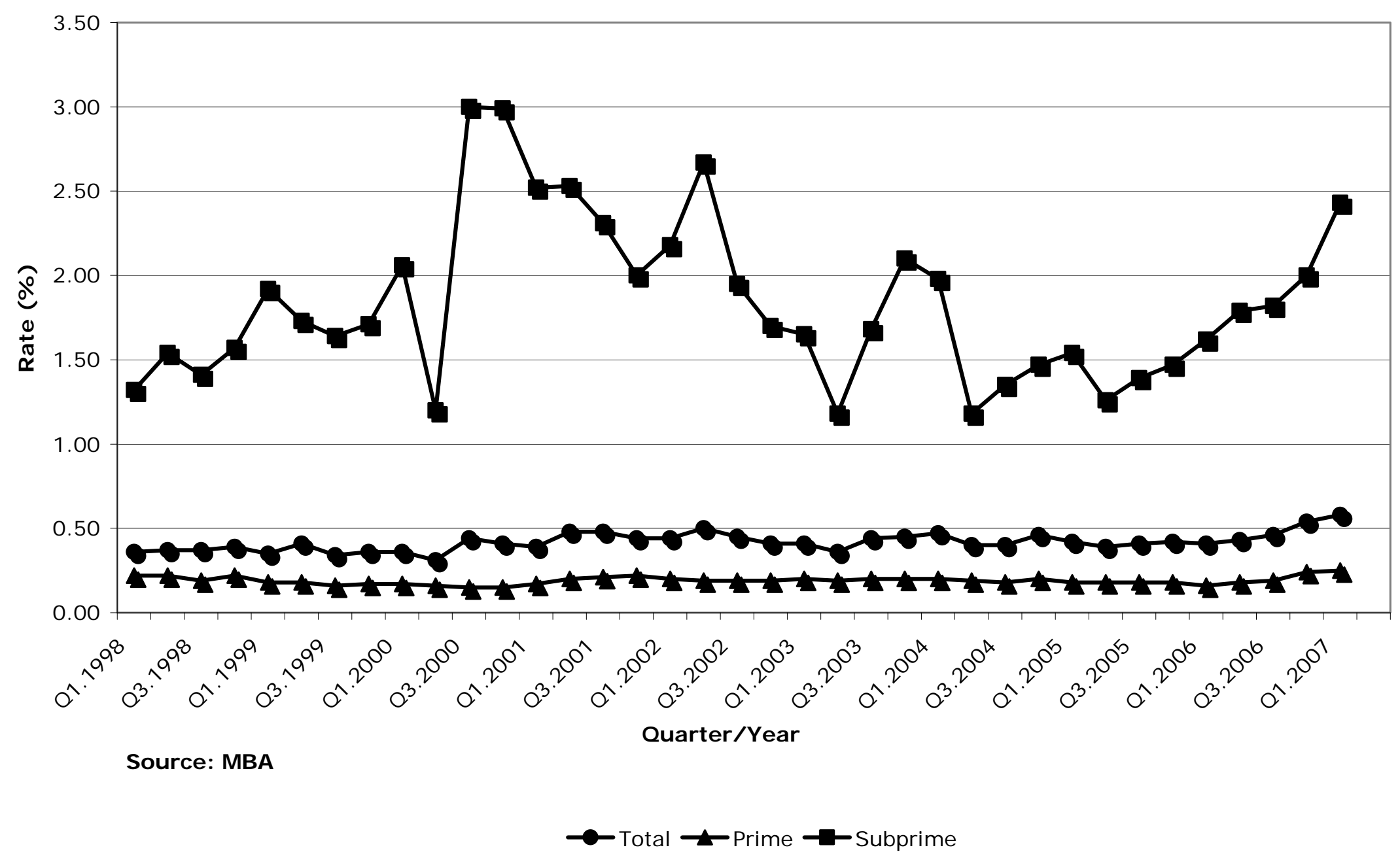




\section{Chart 3: Homes In Foreclosure}

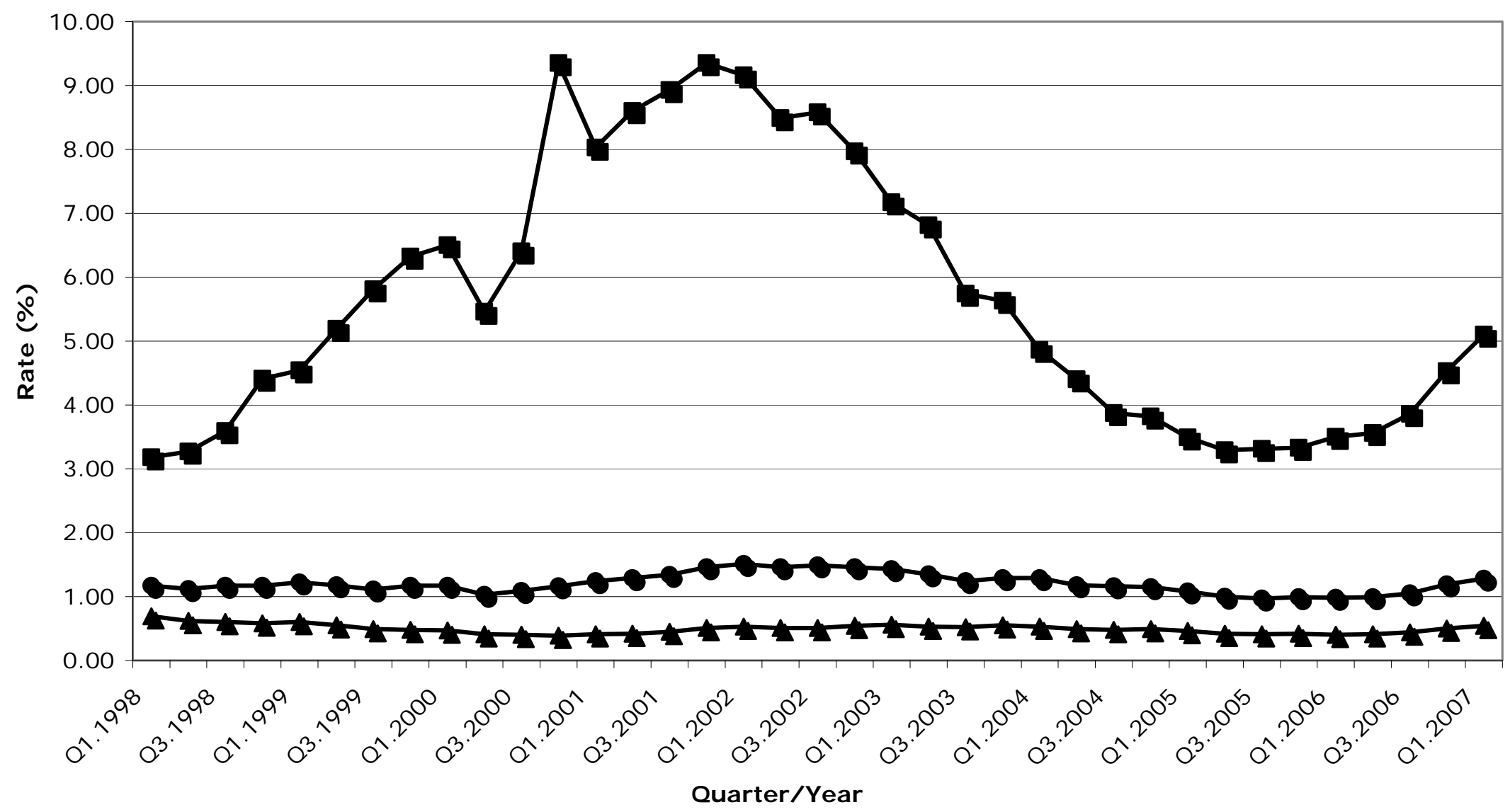

Source: MBA 
Chart 4: House Price Index

Q1- $1980=100$

Q1-1975 to Q1-2007

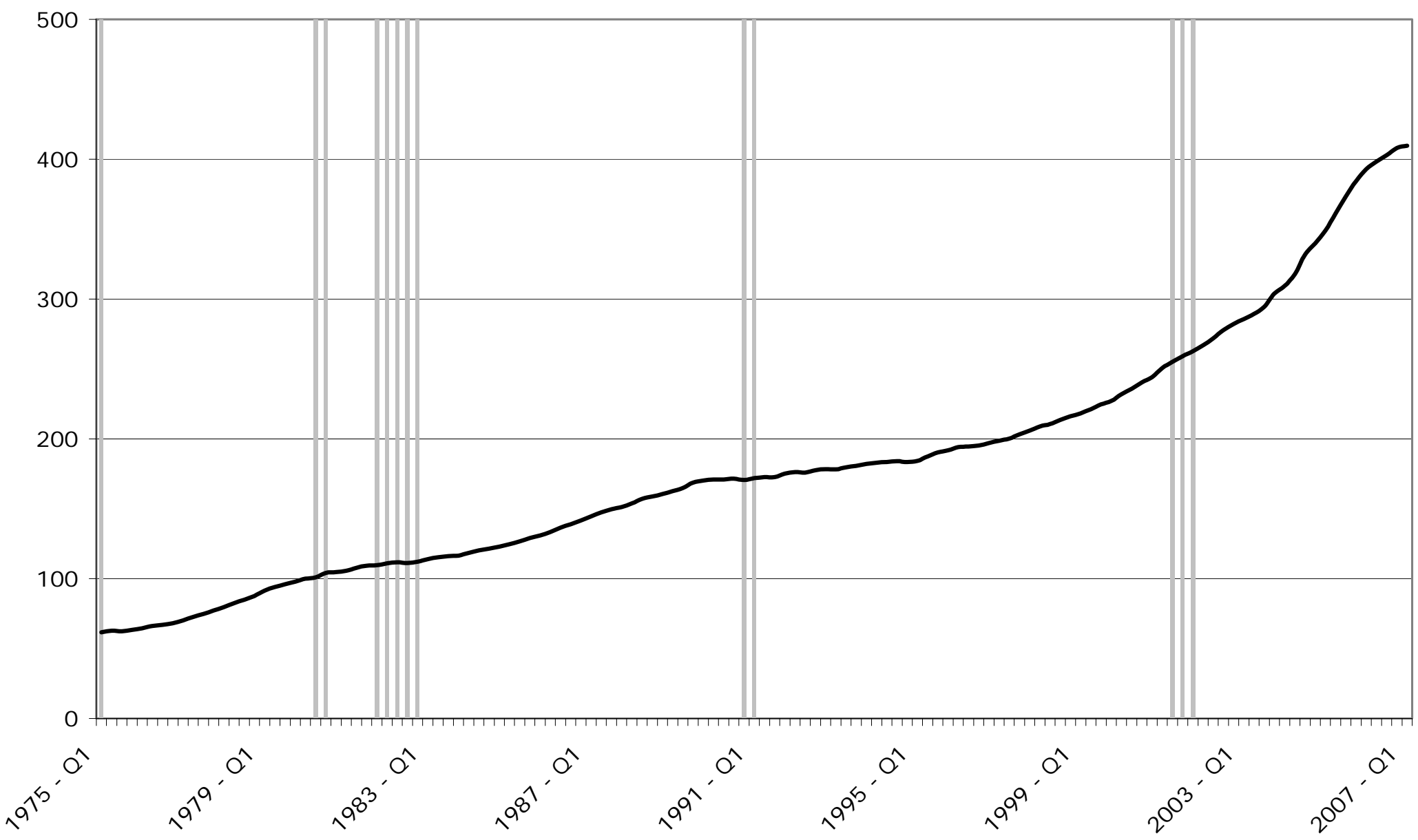

Source: Office of Federal Housing Enterprise Oversight 
Chart 5: Realistic Housing Price Patterns:

"Slow Leaks," not "Bubbles"

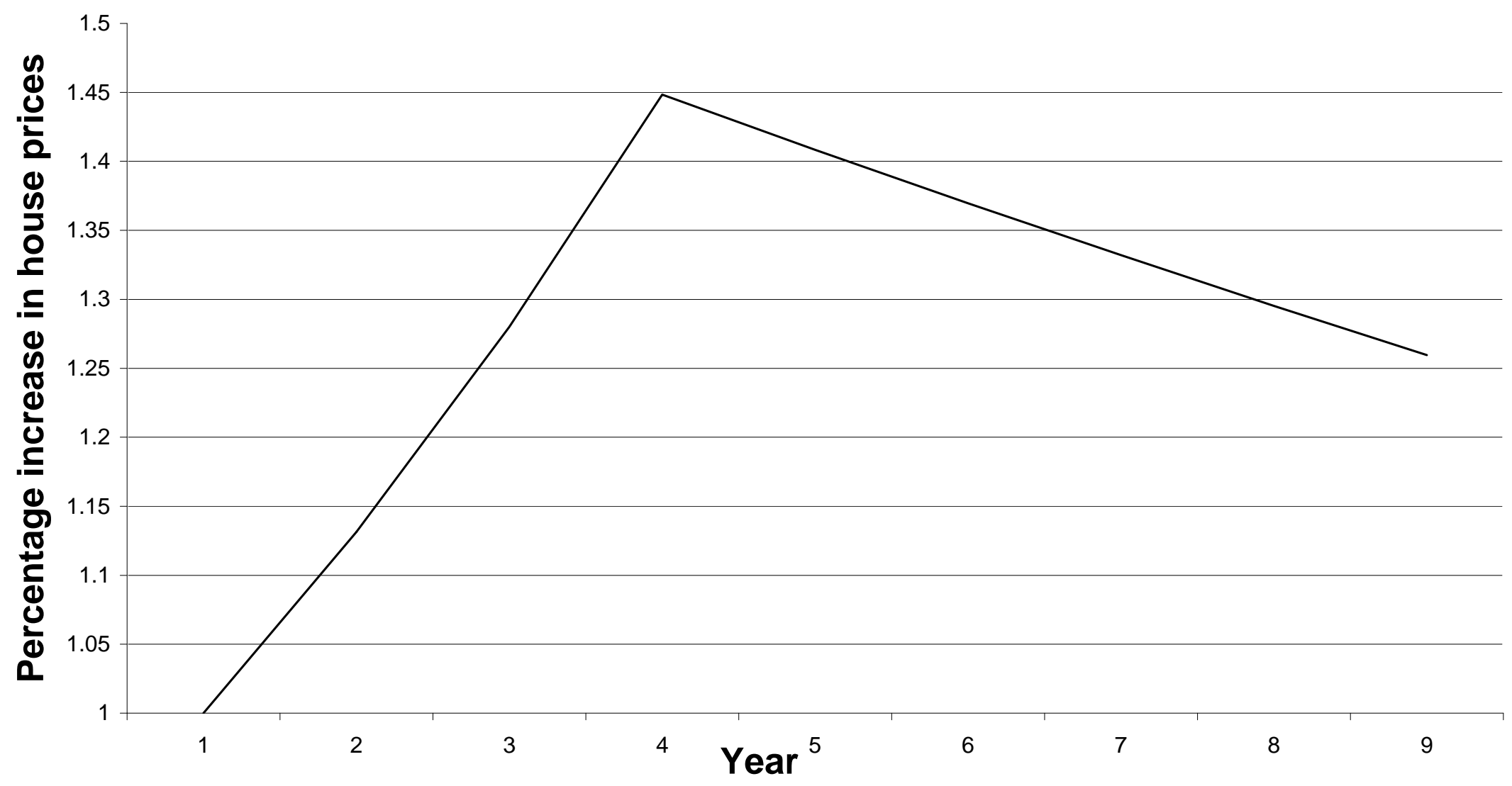

Source: FDIC 
Chart 6: Homeownership Rate: 1994-2006

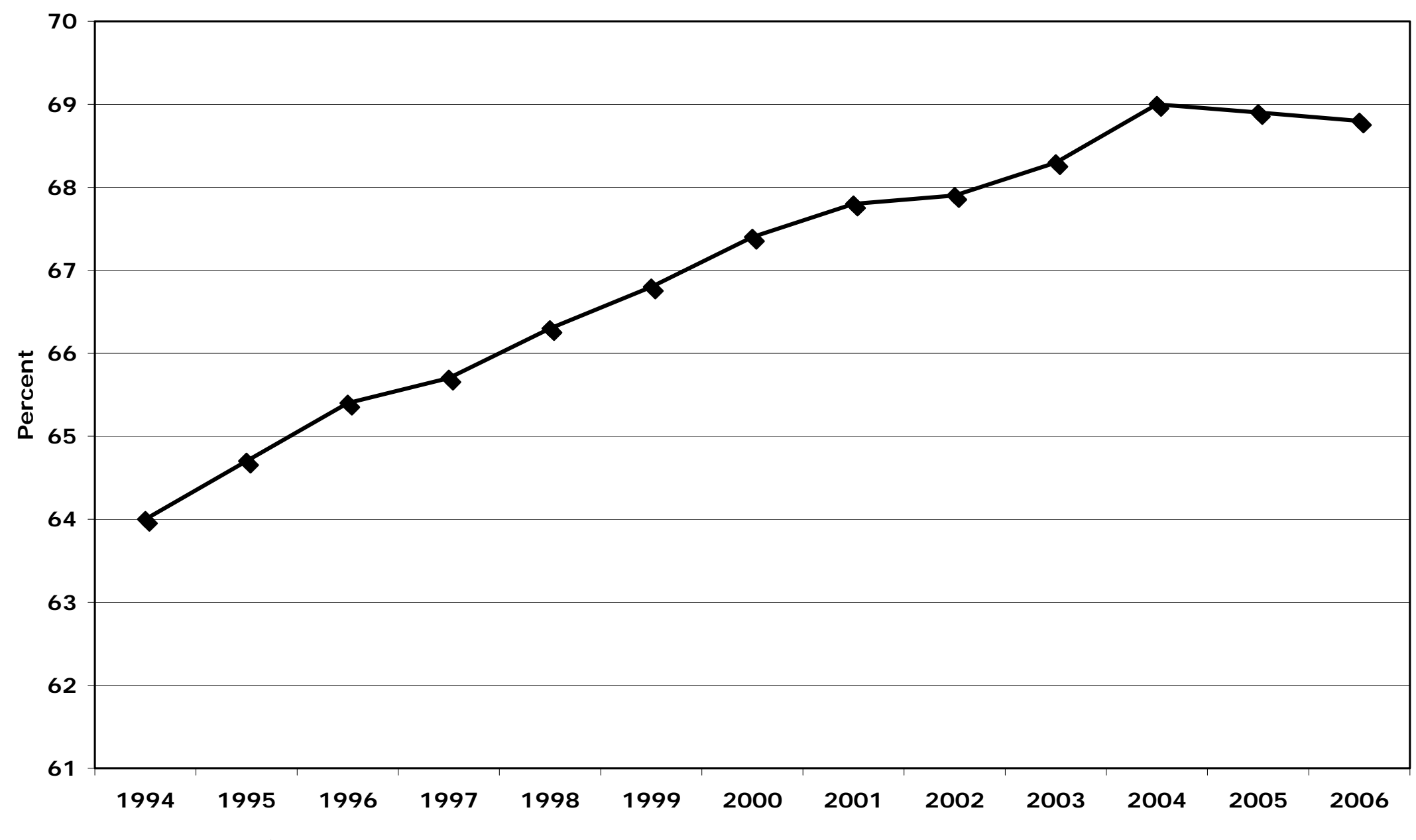

Source: U.S. Census Bureau 
Chart 7: Minority Homeownership Rates: 1994 - 2006

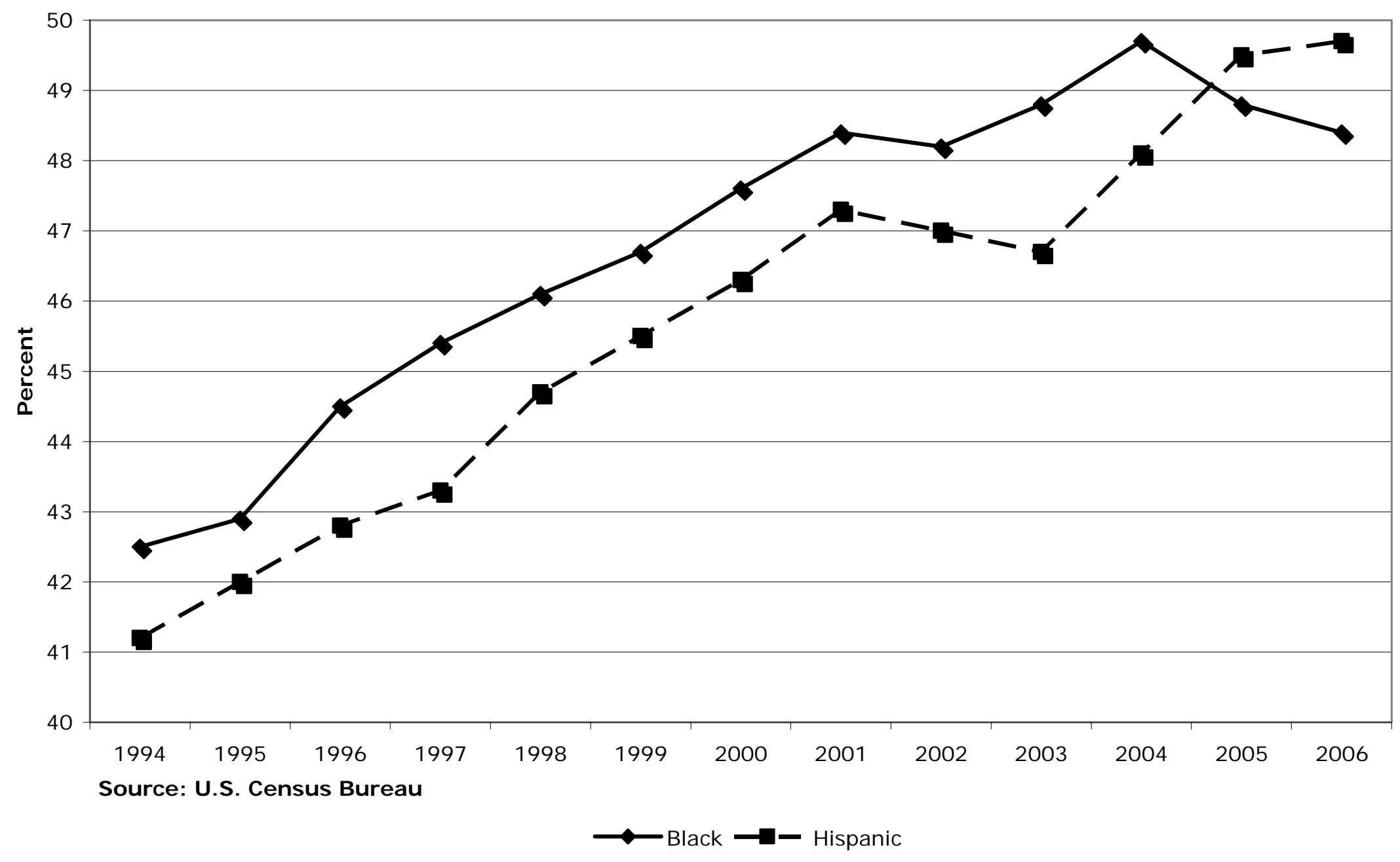

